\title{
Outcome of surgery for laryngotracheal stenosis in grade III and IV subglottic stenosis
}

\author{
HR Davari \\ From 23rd World Congress of the World Society of Cardio-Thoracic Surgeons \\ Split, Croatia. 12-15 September 2013
}

\section{Background}

Treatment for laryngotracheal stenosis is technically challenging and no therapeutic algorithm exists.

\section{Methods}

Thirteen patients with laryngotracheal stenosis were treated. Ten were males and 3 females with an age range of 4-60 years. The cause of airway stenosis was prolong intubation in 10, blunt trauma injury and idiopathic subglottic stenosis in 2 and 1consequence. Preoperative assessment included bronchoscopy, neck and chest CT scan to determine the extension of stenosis. The upper margin of the stricture was $3 \mathrm{~mm}$ to $1.0 \mathrm{~cm}$. below the vocal cords; the stenotic segment extended from 3 to $6 \mathrm{~cm}$. All patients except one had tracheostomy for a long period. Two patients had failed previous resections. In 10 patients dilatation and insertion of Montgomery $\mathrm{T}$ tube was the initial procedure. Pearson's technique was used for laryngotracheal resection. Suprahyoid laryngeal release was performed in 8 . Montgomery $\mathrm{T}$ tube were placed in 12 and left in place for 1 year.

\section{Results}

Decanulation was done with success in all except 2 in first attempt. Circumferential granulation in one patient was excised and reinsertion of $T$ tube for another 6 months was associated with successful decanulation. A kid who had resection at age 6 with poor compliance came back early to re-tracheostomy. He re-operated at age 14 with successful final decanulation. Endoscopic Laser and / or APC were used in 2 patients after $\mathrm{T}$ tube decanulation.

\section{Conclusion}

Surgical management of laryngotracheal stenosis is the treatment of choice. However, primary surgery is not

Correspondence: h1h2hamid@yahoo.co.uk

General Thoracic Surgery, Tehran University of Medical Sciences, Tehran, Iran always feasible. A consequence or combined approach should considered.

Published: 11 September 2013

doi:10.1186/1749-8090-8-S1-0217

Cite this article as: Davari: Outcome of surgery for laryngotracheal stenosis in grade III and IV subglottic stenosis. Journal of Cardiothoracic Surgery 2013 8(Suppl 1):O217.
Submit your next manuscript to BioMed Central and take full advantage of:

- Convenient online submission

- Thorough peer review

- No space constraints or color figure charges

- Immediate publication on acceptance

- Inclusion in PubMed, CAS, Scopus and Google Scholar

- Research which is freely available for redistribution
C Biomed Central
C Biomed Central 